\title{
Correction to: Gender norms and relations: implications for agency in coastal livelihoods
}

\author{
Sarah Lawless $^{1,2} \cdot$ Philippa Cohen $^{1,3} \cdot$ Cynthia McDougall $^{3} \cdot$ Grace Orirana $^{2} \cdot$ Faye Siota $^{2} \cdot$ Kate Doyle $^{4}$
}

Published online: 3 January 2020

(C) The Author(s) 2020

\section{Correction to: Maritime Studies} https://doi.org/10.1007/s40152-019-00147-0

The article Gender norms and relations: implications for agency in coastal

Livelihoods, written by Sarah Lawless et al., was originally published electronically on the publisher's internet portal on 12 September 2019 without open access. With the author(s)' decision to opt for Open Choice, the copyright of the article changed in January 2020 to (C) The Author(s) 2019 and the article is forthwith distributed under the terms of the Creative Commons Attribution 4.0 International License (http:// creativecommons.org/licenses/by/4.0/), which permits use, sharing, adaptation, distribution, and reproduction in any medium or format, as long as you give appropriate credit to the original author(s) and the source, provide a link to the Creative Commons license, and indicate if changes were made.

The original article has been corrected.

The online version of the original article can be found at https://doi.org/ 10.1007/s40152-019-00147-0

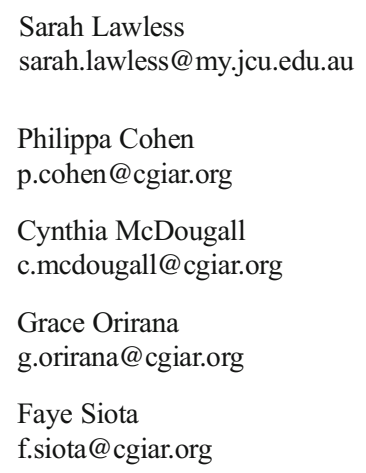

Kate Doyle

k.doyle@promundoglobal.org

1 ARC Centre of Excellence for Coral Reef Studies, James Cook University, Townsville, Australia

2 WorldFish, P.O. Box 438, Honiara, Solomon Islands

3 WorldFish, Jalan Batu Maung, Batu Maung, 11960 Bayan Lepas, Pulau Pinang, Malaysia

4 Promundo, 1367 Connecticut Ave NW, 310, Washington, DC 20036, USA 